\title{
Undergraduate Students' Perceptions toward Social Media Usage and Academic Performance: A Study from Saudi Arabia
}

https://doi.org/10.3991/ijet.v14i03.9340

\author{
Alamri, Mahdi M \\ King Faisal University, Alahsa, Saudi Arabia, \\ mahdi@kfu.edu.sa
}

\begin{abstract}
This study investigated perceptions of undergraduate students toward social media usage. It also examined the relationship of students' usage purpose as well as usage period with their GPA. This study sought to establish the most popular applications that students preferred. Questionnaires were distributed and 132 students enrolled in the current study. Results indicated that there were general positive perceptions toward using social media for academic purposes. There also was a statistical significant relationship between the purpose of social media usage and students' GPA. Findings also revealed that there were no statistically impact of students' usage period of social media on GPA. WhatsApp and Twitter were the most preferred social media options used among students whereas Wiki, Facebook and LinkedIn were the lowest options reported. The findings of this study can be used to recommend the effective ways of incorporating social media into learning activities without affecting students' performance. Implications and recommendations for further research are discussed.
\end{abstract}

Keywords-Social Media, academic performance, higher education

\section{Introduction}

Today's society is permeated with social media due to its ease of use, access and communication with various individuals at the same time. A person can create accounts with different sites such as Facebook, Tumblr, Instagram, LinkedIn, Twitter, MySpace, and Snapchat. In the current changing digital age, universities and colleges are adapting to using technology in their systems thus relying heavily on these mechanisms to enhance students' lives. For instance, the technology is being used to provide students with useful information create and connect learning groups in order to create a convenient learning environment. Through these platforms, students can share and interact with their colleagues, benefit from tutorials and connect with experts on various topics via the internet (Al-Khalifa \& Garcia, 2013). Students can follow the experts and be able to ask questions as well as obtain useful content from them. Such institutions can connect with students by the use of sites such as YouTube, Google Plus groups, Twitter as well as Facebook. Institutions also are using social 
media to market their courses, make an announcement and interact with their students (Porter, 2004). The platforms are proving to be useful in research process especially in the extraction of data and obtaining expert feedback on a particular topic.

The worry is whether the social media is a valuable teaching tool or a source of distraction. For instance, instructors are making use of the platforms to share content and create online discussion groups. Tertiary institutions use social medial in the distance learning model which has gotten ahead of the campus-based model (Aragon, 2003). The online learning is making use of the technological trends and advances to communicate and to enhance the learning experience. Several studies have explored how social media affects students' academic performance (Al-Qoot \& Abu-Jado, 2016; Camilia, Ibrahim, \& Dalhatu, 2013; Junco, Heiberger, \& Loken, 2011; Ravizza, Hambrick, \& Fenn, 2014). While there were some studies showed positive impact on students' academics, others reported evidences that there were either negative or no effects on their academic performance. Most studies, however, recommended that more studies are needed to investigate this issue. Thus, the current study will determine the hypothesis that excessive use of social media can affect the academic performance of the students in universities situated in Saudi Arabia.

\section{Theoretical Background}

\section{$2.1 \quad$ Social media}

Social media or rather social networking is described and explained by Kaplan and Haenlein (2010), as applications that use the internet that allow creating and sharing of user-generated information. Some of the activities that a user can carry out using the technology are the creation of accounts, contribution to a site in the form of reviews, comments, classification as well as sharing of the information through forwarding or tagging. Therefore, the user can interact with other users and share content from one person to another. Curtis (2013) shares social media statistics for reveals that Facebook was leading with 1.1 billion users, Flickr had 87 million users, Twitter's users had been approximately 500 million, and 225 million were using LinkedIn accounts, 25 million users were in MySpace among another platform. Grahl (cited in Alwagait, Shahzad, \& Alim, 2015) illustrated variety of social media forms existed as presented in Table 1.

There is extensive use of social media among students because of the increased access to the affordable internet at homes and colleges. An investigation in Los Angeles University revealed that approximately 94 percent of first-year students were using social media (Subrahmanyam, Reich, Waechter, \& Espinoza, 2008). McFedries (2007) indicates that although Facebook has attracted a considerable following worldwide, Saudi Arabia had more Twitter users. Such platform is highly recommended for use in educational activities like research because it makes the analysis of information easier (Grosseck \& Holotescu, 2011). More so Al-Khalifa (2008) indicates that while 58 percent of students preferred the use of Twitter for academic purposes, 37 percent objected its use. 
Table 1. Forms of social media adapted from Grahl (cited in Alwagait et al., 2015).

\begin{tabular}{|l|l|}
\hline \multicolumn{1}{|c|}{ Social media forms } & \multicolumn{1}{c|}{ Description } \\
\hline $\begin{array}{l}\text { Social networking sites } \\
\text { (SNS) }\end{array}$ & $\begin{array}{l}\text { Services in which users set up a profile in order to establish a connection } \\
\text { with friends or other users, who have similar backgrounds or interests. The } \\
\text { profile contains a users' personal information. SNS provide various ways for } \\
\text { users to interact with one another. Examples of SNS include Facebook, } \\
\text { LinkedIn and Google+. }\end{array}$ \\
\hline Bookmarking sites & $\begin{array}{l}\text { Services that allow users to save search and organize links to various inter- } \\
\text { net resources and websites. Some services will allow the tagging of links in } \\
\text { order for them to be shared easily as well as being searched for. Examples of } \\
\text { booking marking sites include Delicious. }\end{array}$ \\
\hline Micro blogging sites & $\begin{array}{l}\text { Services that combine SNS and blogging but the messages exchanged are } \\
\text { limited in terms of size. Users have to subscribe to the services. Examples of } \\
\text { micro blogging sites include Twitter. }\end{array}$ \\
\hline Media sharing sites & $\begin{array}{l}\text { Services that allow users to upload and share media such as videos and } \\
\text { photos as well as allowing users to comment and tag media. Examples of } \\
\text { media sharing services include YouTube and Flickr. }\end{array}$ \\
\hline Social news sites & $\begin{array}{l}\text { Services that allows other users to vote on news articles and links to external } \\
\text { articles, which are posted by users. The news articles that get the most votes } \\
\text { are displayed more prominently on the site. Examples of social news sites } \\
\text { include Digg and Reddit. }\end{array}$ \\
\hline Blogs and forums & $\begin{array}{l}\text { Blogs are like online diaries of thoughts, which give other users the oppor- } \\
\text { tunity to post comments on the blog postings. Forums allow registered users } \\
\text { to have conversations with other users by post messages. Examples of } \\
\text { blogging sites include WordPress and Blogger. }\end{array}$ \\
\hline
\end{tabular}

The critics of the social media pinpoint various disadvantages associated with these applications on the student. Some of the significant problems are cyberbullying, time wastage and leakage of private information. Cyberbullying comprises of sending threatening or intimidating message to another person through an electronic medium. It may include also sending instant messages, use of blogs or creating accounts in the social media to hurt others, stealing passwords of email accounts or social networking accounts with the intent of harming the users or sending malicious codes such as viruses and Malware (WiredSaftey, 2009).

The vice is rampant at the university as indicated by various studies. For instance, Walker, Sockman, and Koehn (2011) and Zhang, Land, \& Dick (2010) revealed after surveying 134 university students that 62 percent of students had at one time experienced cyberbullying while 40 percent confessed to having participated in cyberbullying. Additionally, some students are growing up at a time when technology has advanced significantly to such an extent that the use of the internet is a daily life affair. With these achievements, the sharing of personal activities and information brings pleasure as well as activate brain an individual's brain. Due to this brain activation and the derived pleasure, the social media has become addictive and time wasting as the student has to put aside important tasks (Tamir \& Mitchell, 2012). Social medial also leads to the display of personal information through user profiles. Although various platforms promise to provide tight security settings, this is not guaranteed. For instance, friends may leak the information or criminals may through social engineering attack users and their friends or families. The attacks may include identity theft, and phishing of information. This is because personal information may be useful to businesses for advertisement, hackers, and predators that browse the internet looking for prey (FBI, 2013). 
Although personal information found in the social is useful to employers especially when they are looking for employees to recruit, personal information displayed on the social media may cause concern to the potential employers. For instance, details or photos related to alcoholic and drug abuse may signify that the student is linked to criminal activities (Havenstein, 2008). Additionally, the information shared on the user profile could cause problems to the company or institution. For instance, one nurse updated her profile information that disclosed confidential medical details of a patient that brought liability to the hospital. The nurse had returned from her shift and was feeling stressed as well as exhausted and decided to update her status, but sadly it turned out to a lawsuit. This shows the importance of separating the social life and work (Cox \& Rethman, 2011).

\subsection{Academic performance}

There has been an escalated demand for internet as well as social media applications among the young generation all over the world. Various studies (Al-Gamal, Alzayyat, Ahmad, 2015; Al-Shdayfat, Hawi, Hamadneh, Albnian, Alzyoud, Logue, 2016; Omekwu, Eke, Odoh, 2014) show the need is high among adolescent, high school as well as undergraduate students. Nevertheless, prime use of social media among university students is to watch movies, play games as well as communicate with friends among others (Al-Qoot \& Abu-Jado, 2016; Ciampa, Thrasher, \& Revels, 2016; Lau, 2017). Conversely, various studies indicate that there has been an increased use of social networking by students to perform academic activities such assignments, learning, and research (Ali, Raja, Nuri Al Amin, \& Iftikhar, 2017; Alwagait et al., 2015; Karpinski, Kirschner, Ozer, Mellott, \& Ochwo, 2013; LeyrerJackson \& Wilson, 2018; Paul, Baker, \& Cochran, 2012; Smith, 2017). They highlighted the benefits of using social networking in learning studies and further research is needed to determine the actual impact of social media in the learning process as well as communication among students and instructors (Al-Qoot \& Abu-Jado, 2016; Bosch, 2009; Green, Wyllie, \& Jackson, 2014).

Although the social media has various advantages, its usage adversely affected academic performance when the networking sites were used for purposes of nonacademic work at the expense of academic studies (Oye, Adam, \& Nor Zairah, 2012). According to a study conducted by Ravizza et al. (2014) on university students using social media to fulfill their social needs revealed that they were negatively affected in their three examinations carried out in the semester as well as their cumulative final examinations. Also, Camilia et al. (2013) carried out a study in Nigeria to determine the impact of social networking on students' academic performance. Findings revealed that the frequent use of networking sites did not affect their performances.

However, some studies indicate that there are benefits of using social media applications such as Facebook, YouTube and other sites in learning. Junco et al. (2011) indicates that using Twitter for co-curricular and academic discussions had a positive impact on the student's academics. For instance, the students who used Twitter doing their assignments achieved higher levels of engagement as well as semester grade point average (GPA) in comparisons to a student who did not use it. This is because 
they were spent more time engaging with their faculty via Twitter away from their traditional classroom activities. The use of Facebook was also useful when it was used to discuss mathematical course content as indicated by GreGory, GreGory, and Eddy (2014). This platform was used outside the lecture halls, and it increased the undergraduate student engagement significantly, their performance as well as their satisfaction in a course dealing in Calculus. These studies' results, consequently, may indicate that using social media to do non-academic work may attain less favorable grades in students academics. Also vice versa, using social media to do academic work may attain more favorable grades in their academics.

\subsection{Students' perceptions}

Many students in the current age are digital natives, and they use internet to connect and interact with family members, friends as well as classmates through software applications or text messaging. Recently, many institutions have embraced the social media and networking sites as tools for learning due to the perception that its usage will be received positively by their students. However, many students do not wish to mix their social and academic lives. To investigate this conflict, various studies have been conducted. Duhaney (2005) shows that technology provides Institutes of Higher Education with huge power to use it to generate innovative ideas as well as a mechanism that changes the way they administer the education and communicate with students. On the other hand, students use information technology effortlessly to chat, and to keep in touch with their friends as well as trusting the information or individuals they meet online. They do so by sharing their profiles details, photos, music or text messages (Lorenzo, Oblinger, \& Dziuban, 2007). The students take the materials in existence, add their comments and share or republish it in the form of print, video or image. Additionally, those students enrolled in online courses request assistances form their instructors more often. They feel more confident when seeking assistance from tutors than their counterparts in the traditional learning environments.

The academic performance is closely linked to formal help-seeking, perceived threat to seek help as well as academic self-efficacy. These students have a preference for seeking help online and also find it more useful (Kitsantas \& Chow, 2007). Students who use technology in their educational process can link with their lifestyle and professional demands (Moore \& Kearsley, 2005). Since young people make use of upcoming technology extensively due to the influence from their friends and family members, they are however expected to evaluate and utilize information obtained online to deepen their learning level (Lorenzo et al., 2007).

A study by Layzell, Brereton, and French (2000) revealed that approximately 50.8 percent of the interviewed students preferred to learn by the use of programs within their control such as video games. The learning management systems (LMSs) were frequently used with 85.3 percent of seniors using it more than first-year students who were ranked at 77.1 percent. Nearly 5.3 percent reported having had a negative experience when using LMSs. Therefore, social media is being used more frequently in institutions of higher learning because it is ubiquitous and thus 85.2 percent use Facebook to maintain connection with their friends. 
The tool of choice for institutions offering Doctoral, Masters, and Bachelor is Facebook. Seniors almost joining the labor market prefer to make use of accounts for LinkedIn than their freshmen counterparts (Caruso \& Salaway, 2008). Since students are having positive perceptions and familiar with social media, institutions are encouraged to adopt various learning technologies to meet the needs of the new breed of students who are in constant use of technology (Elsaadani, 2012) and live in an age that is characterized as a new 'digital generation' (Al-Zahrani, 2011, 2015). Conversely, some students are resentful of use of social media on academic activities, and therefore they wish to have a clear distinction between the use of networking technologies in their social lives and academic activities. Therefore, researchers such as Lohnes and Kinzer, (2007) and Weaver, Spratt, and Nair (2008) concluded that students preferred to use social media in their social life away from academic settings. Many students are concerned with having their instructors as part of their social networks arguing that the social sites should be a realm that is exclusive for students only.

\section{$3 \quad$ Research Objectives, Questions and Definition of Terms}

Recently, social media applications have become the main source of information. However, their impact on academic performance, learning activities as well as students' perceptions toward social media usage continue to be subject of debate. Moreover, there is limited research on the study in the Middle East region, and therefore this study will assist in filling the existing gap. Therefore, this study aimed to identify the following objectives:

- Assess the perceptions of students toward the use of social media in their academic setting.

- Determine the effect of students' purpose of social media usage on the students' academic performances.

- Determine the effect of usage period of social media on the students' academic performances.

- Establish which social media options are available to students as well as rank their preferences.

These objectives were established by the analysis of the data collected in order to answer the following research questions:

- What are students' perceptions toward the use of social media in their academic activities?

- What is the effect of students' purpose of social media usage on academic performance?

- What is the effect of usage period of social media on students' academic performance?

- Which social media options are available and the most favorable among Saudi undergraduate students? 


\section{Definition of Terms}

- Perceptions: refers to opinion held by students and based on how social media seems.

- Academic performance: performance outcomes that indicate the level to which the student has attained specific learning goals (Ali et al., 2017). In this study, it refers to students' cumulative GPA.

- Social Media: applications that use the internet and allow users to create and share of user-generated information (Kaplan \& Haenlein, 2010).

\section{$5 \quad$ Methodology}

The aim of the current study was to examine perceptions of Saudi undergraduate students toward social media usage. It also sought to explore the relationship between students' social media usage period as well as students' purpose of using social media and their academic performance (cumulative GPA). Additionally, it addressed the most popular sites that were favorable among students and had impact on academic activities as well as other factors which negatively affect their grades. Accordingly, a quantitative method was followed for the purpose of this study that relied on a printed questionnaire for data collection. This selection was as a result of the nature of information that was required and the type of analysis to be carried out. The questionnaire content was built according to the literature reviewed as well as the consideration of the context nature in which the study took a place. It consisted of three main sections that are 1) demographic information (e.g. gender, age, academic level, GPA, and how the participant accessed the internet such as home, Smartphone or computer), 2) social media usage and the preferable social media sites, and 3) students' perceptions toward the use of social media (22 items). The third section focused on three subsections which were students' views about a) enhancing interactions and communications between teachers and students, and between students themselves in the social media (6 items), b) the support of social media for learning activities (11 items), and c) social media roles in supporting student-centered learning strategies ( 5 items). The questionnaire content was reviewed be several experts from Education College as a process of validity. Also, it was pre-tested with a small group of respondents prior to the distribution phase. A Likert's 5-point scale was applied; from 5= strongly agree to $1=$ strongly disagree for favorable opinions and the reverse order for unfavorable views.

The population of the study targeted was all undergraduate students who enrolled in Education College at King Faisal University in Saudi Arabia. Many hard copies of the questionnaire were distributed and the respondents were 132 undergraduate students (56 Male \& 76 female) who registered in 2016-2017 academic year. Participants were from the first to forth university year of their study. They were provided with an explanation of the purpose of the study and, then, were asked to participate voluntarily after obtaining their consent. It was asserted to participants that confidential date would be used for research purposes and they had a right to withdraw from completing the survey anytime they preferred. In order to insure the heterogeneous distribu- 
tion and a representative sample, questionnaires were randomly distributed to students enrolled in compulsory courses which included students from different disciplines. In addition, they were disseminated to the available students who were at service areas in the college.

Collected questionnaires were sorted, reviewed, and unfinished questionnaires were excluded. Then, all completed data were coded and analyzed. Analyses was done by using Statistical Package for Social Sciences (SPSS) software. Descriptive statistics include frequencies, percentages, means, and standard deviations as well as correlation test and One-Way ANOVA were used in order to answer the research questions. The questionnaire's reliability was also assessed and Cronbach's alpha was 0.81 , that indicated high reliability.

\section{Results}

There were 132 questionnaires filled, 56 (42.4\%) were male respondents while 76 $(57.6 \%)$ were female respondents. Respondents were from different university levels (first year $18.9 \%$, second year $25.8 \%$, third year $33.3 \%$, and fourth year $22 \%$ ). The majority of respondents $(71.3 \%)$ were between 19 and 22 years old while 15.9 percent were 18 years old and 12.9 percent were 23 years old. Although they were students from different departments in Education College, the majority of them (43.9\%) were from Education Technology department and 25\% from Art Education, 13.6\% Physical Education, $11.4 \%$ Kindergarten, and 6.1\% Special Education. In addition, almost 32 percent of respondents had 3.74 or less GPA (31.8\%), $45.5 \%$ between 3.75 to 4.49 GPA, and $22.7 \%$ between 4.5 to 5.00 GPA (see Figure 1). Most respondents $(60.6 \%)$ were using the Internet via their smartphones while about 23 percent from homes and about 15 percent from university. Surprisingly, results indicated that all respondents $(100 \%)$ were familiar with the use of social media and they reported that the purposes of using social media were educational $(30.3 \%)$, personal $(47 \%)$, and occupational $(22.7 \%)$. Results showed that 22 percent of respondents used social media less than one hour daily, about half of participants $(50.8 \%)$ between one to less than three hours each day, and over a quarter of respondents $(27.3 \%)$ spent three hours or more on social media each day.

Research Question 1: what are students' perceptions toward the use of social media in their academic activities?

Participants in the current study were generally had a positive perceptions and they were satisfied and encouraged with using social media in their learning activities. As demonstrated in Table 2, participants reported that in the learning process, social media commonly saves much of their times and efforts $(M=4.83, S D=.37)$. Almost all of them highly agreed that using social media supports self-learning $(M=4.62$, $S D=.52)$, collaborative learning $(M=4.42, S D=.55)$, and contributes to enhance learners' knowledge and skills $(M=4.61, S D=.60)$. In addition, over 90 percent of respondents agreed that social media is rich environment to complete many academic activities $(M=4.55, S D=.65)$ and they highly satisfied with it $(M=4.51, S D=.60)$ although there were about seven percent were not sure about it. Results also showed 
that social media supports interaction between learners and teachers which lead to overcome learners' fears, increase familiarity and encourage stimulation $(M=4.42$, $S D=.50)$. This in turn enhances students to publish academic multimedia $(M=4.48$, $S D=.61)$, documents and research's abstracts $(M=4.16, S D=.90)$, and online surveys $(M=3.84, S D=1.03)$.

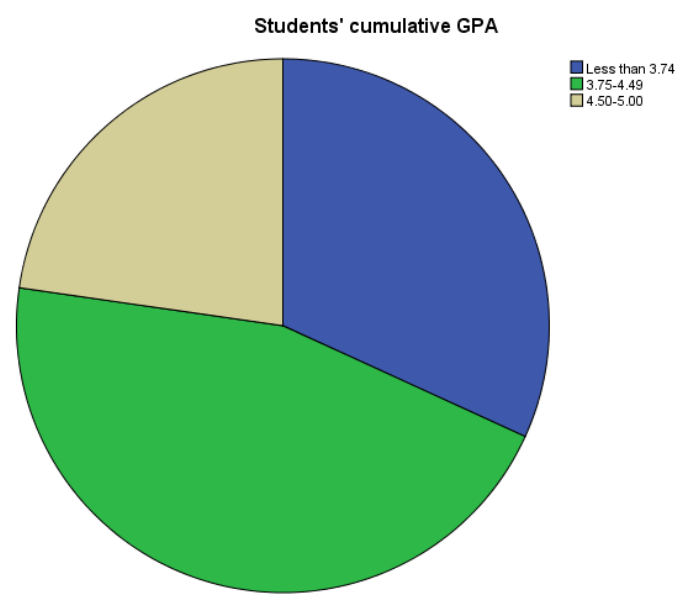

Fig. 1. Distribution of students' cumulative GPA.

Table 2. Students' perceptions toward the use of social media in their academic activities $(n=$ 132)

\begin{tabular}{|l|c|c|}
\hline \multicolumn{1}{|c|}{ Statement } & Mean & SD \\
\hline I am sure that using social media in the learning process will save much time and efforts & 4.83 & .37 \\
\hline $\begin{array}{l}\text { Social media supports my self-learning } \\
\text { I imagine that social media contributes to enhance learners' knowledge and skills through } \\
\text { discussing various subjects such as scientific, religious, literary, sports, social subjects }\end{array}$ & 4.62 & .52 \\
\hline $\begin{array}{l}\text { I believe that social media is rich environment to carry out many educational activities that } \\
\text { need to be accomplished }\end{array}$ & 4.55 & .60 \\
\hline I am satisfied when social media is used as a mean to implement the course's activities & 4.51 & .60 \\
\hline $\begin{array}{l}\text { Social media enables me to publish variety of multimedia (e.g. texts, graphics, images, } \\
\text { animations, sounds and videos files) which related to the course content }\end{array}$ & 4.48 & .61 \\
\hline I perceive that social media supports collaborative learning with my peers & 4.42 & .55 \\
\hline $\begin{array}{l}\text { Social media supports the continuous interaction between learners and their teachers which } \\
\text { contribute to overcome learners' fears, increasing familiarity, and encourage stimulation in } \\
\text { the learning }\end{array}$ & 4.42 & .50 \\
\hline $\begin{array}{l}\text { Social media enables me to publish documents and research's abstracts that related to the } \\
\text { course content }\end{array}$ & 4.16 & .90 \\
\hline $\begin{array}{l}\text { I perceive that my social media usage increases the opportunities of my academic } \\
\text { excellence }\end{array}$ & 4.03 & .77 \\
\hline $\begin{array}{l}\text { I perceive that social media provides instant feedback on my course's questions which help } \\
\text { me to solve educational problems I face }\end{array}$ & 4.00 & .75 \\
\hline $\begin{array}{l}\text { Social media is an appropriate mean to increase our motivation toward learning } \\
\text { Social media provides me with updated news about the course }\end{array}$ & 3.99 & 3.98 \\
\hline
\end{tabular}




\begin{tabular}{|c|c|c|}
\hline $\begin{array}{l}\text { Social media increases the learners' coherence in the course which contributes to increase } \\
\text { the responsibility toward our learning }\end{array}$ & 3.97 & .75 \\
\hline I perceive that course's assignments should be delivered through social media & 3.96 & .79 \\
\hline $\begin{array}{l}\text { I perceive that social media is an appropriate way for enhancing self-assessment skills with } \\
\text { regard to the outcomes of educational projects }\end{array}$ & 3.86 & .79 \\
\hline Social media enables me to publish online surveys about the course & 3.84 & 1.03 \\
\hline Social media participates in the dissemination of knowledge and creativity among learners & 3.73 & .78 \\
\hline $\begin{array}{l}\text { I perceive that social media provides accurate and reliable information about the course } \\
\text { subjects }\end{array}$ & 3.50 & .94 \\
\hline I participate in dialogues and critical readings existing on course's topics in social media & 3.10 & .52 \\
\hline
\end{tabular}

Furthermore, it was obvious that respondents perceived themselves as motivated, responsible and persistent toward their learning when using social media. Over three quarter of participants agreed that social media provides an instant feedback on their questions $(M=4.00, S D=.75)$ as well as updated news about courses $(M=3.98, S D=$ $.75)$. This increased their motivation $(M=3.99, S D=.72)$ and responsibility $(M=3.97$, $S D=.75$ ) toward the learning. They, also, considered social media as an appropriate mean for enhancing their self-assessment skills with regard to the outcomes of educational projects $(M=3.86, S D=.79)$. Therefore, over 80 percent of participants revealed that their usage of social media increases the opportunities of academic excellence $(M=4.03, S D=.77)$ although there were some students (14.4\%) who not sure or did not agree with that $(4.5 \%)$.

However, some respondents had neutral perceptions and sometimes were disagreeing toward the use of social media in the learning. Nearly half of the respondents $(47 \%)$ were not sure with regard to the participation of the social media in disseminating the knowledge and creativity among learners $(M=3.73, S D=.78)$. Meanwhile, the rest of respondents were agree with this statement. Additionally, there was few doubt $(21.2 \%)$ toward providing accurate and reliable information in social media regarding the course subjects $(M=3.50, S D=.94)$ although over half of respondents $(51.5 \%)$ agreed that they trusted the information in this environment. As a final point, over three quarter of respondents $(76.5 \%)$ were not sure that they participate in dialogues and critical readings existing on course's topics in social media $(M=3.10, S D=.52)$ and about eight percent were disagreed. Only about 15 percent agreed that they participate critically in courses' dialogues in social media.

Research Question 2: what is the effect of students' purpose of social media usage on academic performance?

Figure 2 demonstrates that students' purposes of using social media were educational (30.3\%), personal (47\%), and occupational $(22.7 \%)$. In order to investigate whether these purposes influence students' academic performance, One-Way ANOVA was conducted to determine differences between groups. Results, as presented in Table 3, showed that there were statistically significant differences at 0.05 between groups regarding the impact of students' purposes on GPA.

A least significant difference (LSD) test was also conducted to clearly identify the impact of students' purposes of using social media on academic performance. Results revealed that the differences of the statistical significance at 0.05 were in favor of the all three purposes that are educational, personal occupational purposes (see Table 4). 


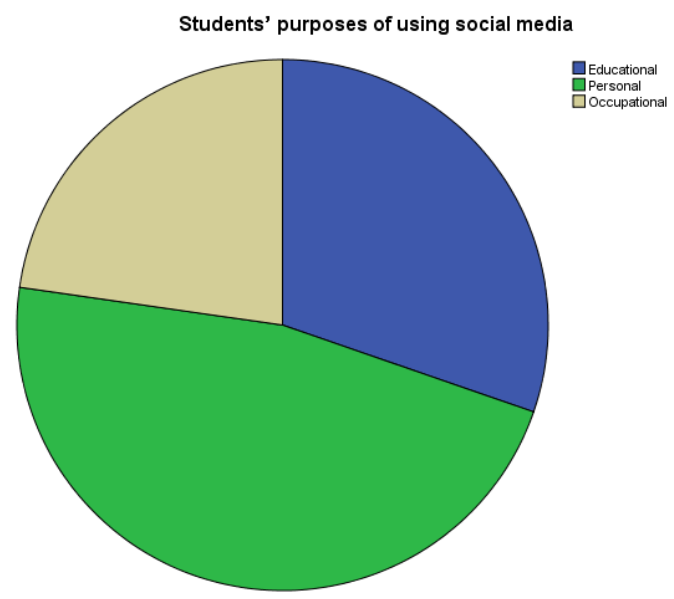

Fig. 2. Distribution of students' purposes of using social media.

Table 3. Impact of students' purposes of using social media on academic performance (GPA)

\begin{tabular}{|c|c|c|c|c|c|}
\hline & Sum of Squares & df & Mean Square & F & Sig. \\
\hline Between Groups & 5.567 & 2 & 2.784 & 5.495 & .005 \\
\hline Within Groups & 65.342 & 129 & .507 & & \\
\hline Total & 70.909 & 131 & & & \\
\hline
\end{tabular}

Table 4. One-Way ANOVA purposes vs. academic performance (cumulative GPA)

\begin{tabular}{|c|c|c|c|c|c|c|}
\hline \multicolumn{7}{|c|}{ LSD Test } \\
\hline \multirow[b]{2}{*}{ (I) Purpose } & \multirow[b]{2}{*}{ (J) Purpose } & \multirow{2}{*}{\begin{tabular}{|c|} 
Mean Difference \\
(I-J)
\end{tabular}} & \multirow[b]{2}{*}{ Std. Error } & \multirow[b]{2}{*}{ Sig. } & \multicolumn{2}{|c|}{ 95\% Confidence Interval } \\
\hline & & & & & Lower Bound & Upper Bound \\
\hline \multirow{2}{*}{ Educational } & Personal & $-.46452-^{*}$ & .14434 & .002 & $-.7501-$ & $-.1789-$ \\
\hline & Occupational & $-.40000-^{*}$ & .17189 & .022 & $-.7401-$ & $-.0599-$ \\
\hline \multirow{2}{*}{ Personal } & Educational & $.46452^{*}$ & .14434 & .002 & .1789 & .7501 \\
\hline & Occupational & .06452 & .15828 & .684 & $-.2487-$ & .3777 \\
\hline \multirow{2}{*}{ Occupational } & Educational & $.40000^{*}$ & .17189 & .022 & .0599 & .7401 \\
\hline & Personal & $-.06452-$ & .15828 & .684 & $-.3777-$ & .2487 \\
\hline
\end{tabular}

Research Question 3: what is the effect of usage period of social media on students' academic performance?

As shown in Figure 3, results of students' usage period of social media showed that about a quarter $(22 \%)$ of respondents used social media less than one hour each day, over half $(50.8 \%)$ of them spent between one to less than three hours a day, and over a quarter $(27.3 \%)$ spent three hours or more daily on social media applications.

Correlation test was used to determine the statistical significance of students' usage period with academic performance. Results indicated that there were no statistical significant differences at 0.05 of students' usage period on academic performance (see Table 5).

Research Question 4: which social media options are available and the most favorable among Saudi undergraduate students? 
In Table 6, there were eleven social media options used by students. Over a quarter $(27.3 \%)$ of respondents reported that WhatsApp was the most social media used each day. It was followed by Twitter at $19.7 \%$, Snap Chat at $13.6 \%$, Instagram at $12.9 \%$, and YouTube at $9.8 \%$. However, the lowest social media options used among students were Wiki (3.8\%), Facebook and LinkedIn (3\%), and at 2.3 percent for Blogs, Flickr and BBM.

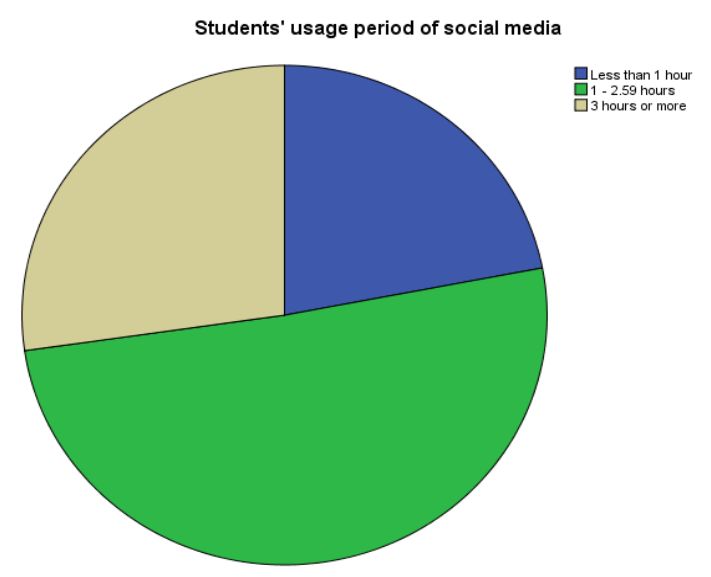

Fig. 3. Distribution of students' usage period of social media.

Table 5. Correlation test students' usage period vs. academic performance (cumulative GPA)

\begin{tabular}{|l|l|c|c|}
\hline \multicolumn{2}{|c|}{} & GPA & Period \\
\hline \multirow{4}{*}{ GPA } & Pearson Correlation & 1 & .009 \\
\cline { 2 - 4 } & Sig. (2-tailed) & 132 & .915 \\
\cline { 2 - 4 } & $\mathrm{N}$ & .009 & 132 \\
\hline \multirow{3}{*}{ Period } & Pearson Correlation & .915 & 1 \\
\cline { 2 - 4 } & Sig. (2-tailed) & 132 & 132 \\
\cline { 2 - 4 } & $\mathrm{N}$ & & \\
\hline
\end{tabular}

Table 6. Favorable social media options

\begin{tabular}{|l|l|c|c|c|c|}
\hline \multicolumn{2}{|c|}{} & Frequency & Percent & Valid Percent & Cumulative Percent \\
\hline \multirow{7}{*}{ Valid } & 4 & 3.0 & 3.0 & 3.0 \\
\cline { 2 - 6 } & Facebook & 26 & 19.7 & 19.7 & 22.7 \\
\cline { 2 - 6 } & Twitter & 5 & 3.8 & 3.8 & 26.5 \\
\cline { 2 - 6 } & Wiki & 3 & 2.3 & 2.3 & 28.8 \\
\cline { 2 - 6 } & Blogs & 13 & 9.8 & 9.8 & 38.6 \\
\cline { 2 - 6 } & YouTube & 3 & 2.3 & 2.3 & 40.9 \\
\cline { 2 - 6 } & LBM, MSN, etc. & 4 & 3.0 & 3.0 & 43.9 \\
\cline { 2 - 6 } & SinkedIn & 18 & 13.6 & 13.6 & 57.6 \\
\cline { 2 - 6 } & Whap Chat & 36 & 27.3 & 27.3 & 84.8 \\
\cline { 2 - 6 } & Instagramp & 17 & 12.9 & 12.9 & 97.7 \\
\cline { 2 - 6 } & Flickr & 132 & 100.0 & 100.0 & 100.0 \\
\cline { 2 - 6 } & Total & & & & \\
\hline
\end{tabular}


All respondents in this study confirmed to have an account in the selected options. This proves that they found it useful to have social media profiles to satisfy their needs and thus they used them as support tools. They also relied heavily on established platforms such as WhatsApp and Twitter to perform their academic activities. Figure 4 below shows the distribution of the favorable social media options.

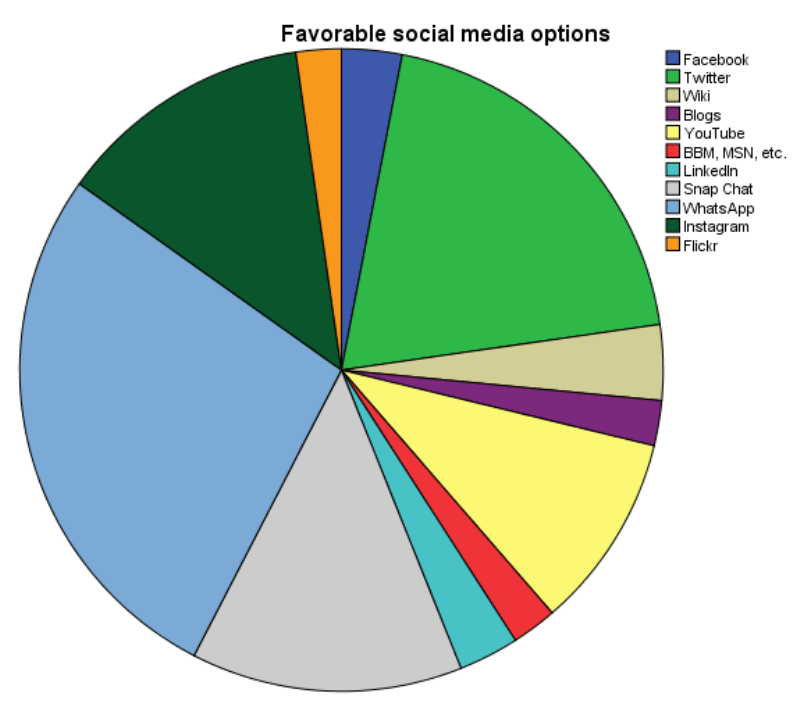

Fig. 4. Distribution of favorable social media options.

\section{$7 \quad$ Discussion}

This study aimed to investigate Saudi undergraduate students' perceptions toward the use of social media. It also sought to explore the relationship between students' social media usage, purpose and period, and their academic performance (cumulative GPA). Additionally, it addressed the most popular social media options that were favorable among students and had impact on academic activities as well as other factors which may negatively affect their grades.

The results indicated general positive perceptions among Saudi undergraduate students toward using social media in the learning activities. Most students reported that using social media in the learning activities supports and enhances self-learning, collaborative learning and their skills. It is considered as an appropriate mean for enhancing learners' self-assessment skills, increasing motivation and responsibility toward the learning. Consequently, students agreed that their use of social media increases the opportunities of academic excellence. However, students had neutral perceptions with regard to the role of using social media in possessing the knowledge and creativity among students. Additionally, majority of students were hesitate to participate in dialogues and critical readings as well as toward providing an accurate and reliable information in the social media. 
Positive perceptions toward using social media in the learning activities were consistent findings of several studies. They reported that students responded positively to the academic use of social media (Al-Shdayfat, 2018; Ross \& Myers, 2017). They also reported that the prime factor that persuaded them to adopt social media was usefulness (Ali et al., 2017). However, unlike the study of Ali et al. (2017) which showed that information quality was a key factor in using social media, finding of the current study reported that students disagreed $(21.2 \%)$ and were hesitate $(17.4 \%)$ toward providing an accurate and reliable information in the social media. This may due to social media applications in Saudi Arabia are still considered as informal way in which students can meet and discuss subjects' content as well as post many entertaining contents with less supervision from instructors. Students, furthermore, mostly register in such applications under anonymous identities and post massive amount of comments. All these practices may hinder students from contributing rationally in dialogues and critical readings in the social media. Nevertheless, results in the present study support other findings of Junco et al. (2011) and GreGory et al. (2014) which revealed that students who participate actively in social media groups were highly engaged in the learning activities and perceived higher grade point average (GPA).

Results furthermore showed that there were statistically significant impact of students' purposes of using social media on academic performance (cumulative GPA) in favor of the all purposes which were educational, personal and occupational purposes. However, personal purpose of using social media applications was the highest mean compared to the lowest mean recorded for the educational purposes. This may be considered as a logic finding particularly among the Saudi universities' students who have high GPA. It could be justified that students who had higher GPA mostly desire and concentrate on studying from textbooks, class notes and materials provided by the instructor and keep using social media applications for the entertainment activities. This is highly consistent with study of Al-Qoot and Abu-Jado (2016) as well as the results reported in this study that showed students' perceptions were neutral with regard to the role of using social media in possessing the knowledge and creativity as well as toward providing an accurate and reliable information in the social media.

On the other hand, students with less GPA may prefer to learn and find information by the easiest way using social media applications. They generally lacked balance in their usage and they inclined more toward their social lives than in academic activities. Although they have accounts in many social media applications, they are mostly exploiting them for their social lives activities and entertainment rather than any other purposes. From educators' view point, there is a little attention and interest of employing social media applications in the educational settings in a formal way although there were few attempts. These results are consistent with Lau's (2017) findings which revealed that there was a significant predictor of academic performance when using social media for non-academic purposes. Ciampa et al. (2016) asserted that in spit of students preferred using social media technologies primarily for communication with friends, they generally font not using them for academic purposes.

In addition, findings revealed that there were no statistically impact of students' usage period of social media on academic performance. This may indicate that the most reasonable time spent on the social media each day is between one and three 
hours without affecting academic performance. This result is compatible with results of Alwagait et al. (2015) and Camilia et al. (2013) which showed that there were no relationship between students' frequent use of social media and their academic performance. However, other studies (Leyrer-Jackson \& Wilson, 2018; Paul et al., 2012; Ravizza et al., 2014) revealed that there were a statistically significant negative relationship between students' academic performance (GPA) with the amount of time spent using social media.

All students in this study were familiar with the use of social media and WhatsApp was the most preferred social media option followed by Twitter. On the other hand, the lowest social media options used among students were Wiki, Facebook and LinkedIn. This result is inconsistent with other works of Afify and Al-Qoot (2017) as well as Alwagait et al. (2015). Nevertheless, it is consistent with study of Al-Qoot and Abu-Jado (2016) which showed that Twitter and WhatsApp were highly preferred social media options to be used in academic and social life situations. In the current study, it can be justified that the high rate of smartphones ownership (60.6\%) among students may led to increase the accessibility to the Internet and social media in the academic activities. The availability of cheaper data services in Saudi Arabia has also contributed to the broad use of the social media to keep in touch with families, friends and for academic activities. Thus, many instructors in Education College usually encourage students informally to create groups for their courses in WhatsApp to provide a supplementary support and use them for academic purposes. They also have profiles on Twitter and exchange thoughts with students and answer their academic questions. Using WhatsApp and Twitter as most popular options among students was, moreover, due to carrying out discussions with other peers and they both linked students with experts who provided them with additional details on specific subjects. Not like other social media options, these two options were highly used to keep in touch with both friends in the courses and families.

\section{Conclusion and Recommendations}

The study concludes that an extreme use of social media with no authentic supervision from educators or accurate planning to employ its applications may affects academic performances of undergraduate students in Saudi Arabia. Such technologies which are recently widespread used among students should be incorporated besides active learning approaches such as problem-based learning, collaborative learning, and flipped classroom as supplementary tools in order to promote learning outcomes. Students additionally should be directed and learned how to manage their times properly when using social media for educational purposes. Although the present study may forms a basis for additional research on social media in Saudi Arabia, it was hindered by two limitations. The total sample of the study was students from only the College of Education. Thus, the findings maybe a subject of generalization issues. Secondly, the number of students who involved in this study could be considered as a small size of sample. However, further research is recommended with large sample sizes from different colleges at the same university. In addition, empirical and qualita- 
tive studies to examine deeply the relationship between social media usage and students' learning outcomes as well as thinking skills are needed. Due to the vital role of educators in employing social media applications in the learning and teaching process, more research should be done to explore faculty members' perceptions and attitudes towards using social media in the learning process.

Data availability: The questionnaire data used to support the findings of this study are available from the author upon request.

\section{Acknowledgement}

The Author acknowledges the Deanship of Scientific Research at King Faisal University for the financial support under grant (186007).

\section{References}

[1] Afify, M. K., \& Al-Qoot, A. M. (2017). Perceptions of preparatory year students at Dammam University towards the use of social networks to support and strengthen the teaching and learning process. Arab International Journal of Informatics, 5(9), 1-15.

[2] Al-Gamal, E., Alzayyat, A., \& Ahmad, M.M. (2015). Prevalence of Internet Addiction and Its Association with Psychological Distress and Coping Strategies Among University Students in Jordan. Perspectives in Psychiatric Care, 52(1), 49-61. https://doi.org/10.1111/ppc.12102

[3] Al-Khalifa, H. S., \& Garcia, R. A. (2013). The state of social media in Saudi Arabia's higher education. International Journal of Technology and Educational Marketing (IJTEM), 3, 65-76. https://doi.org/10.4018/ijtem.2013010105

[4] Al-Khalifa, H. S. (2008). Twitter in academia: a case study from Saudi Arabia. eLearn, 2008(9), 2. https://doi.org/10.1145/1454105.1454109

[5] Al-Qoot, A. M., \& Abu-Jado, M. M. (2016). The use of social media and its relationship with academic excellence through students' attitudes of Education College, Imam Abdulrahman bin Faisal University. Educational and Social Studies, 22(4), 921-956.

[6] Al-Shdayfat, N. M. (2018). Undergraduate student nurses' attitudes towards using social media websites: A study from Jordan. Nurse education today, 66, 39-43. https://doi.org/10.1016/j.nedt.2018.03.017

[7] Al-Shdayfat, N., Hawi, N., Hamadneh, S.H., Albnian, F., Alzyoud, S., \& Logue, T. (2016). Internet addiction among school adolescents in Northeastern Jordan. World Journal of Medical Sciences 13(4), 218-224.

[8] Al-Zahrani, A. M. (2011). Preparing Pre-service Teachers for the Effective Use of Educational Technology in Saudi Arabia. Unpublished Ph.D Thesis, La Trobe University, Melbourne, Australia.

[9] Al-Zahrani, A. M. (2015). From passive to active: The impact of the flipped classroom through social learning platforms on higher education students' creative thinking. British Journal of Educational Technology, 46(6), 1134-1150. https://doi.org/10.1111/bjet.12353

[10] Ali, M., Raja, R. A. I. B., Nuri Al Amin, B. E., \& Iftikhar, B. (2017). Determining the academic Use of Social Media with Technology Acceptance Models. NFC IEFR Journal of Engineering and Scientific Research, 5. 
Paper-Undergraduate students' perceptions toward Social Media usage and academic performance...

[11] Alwagait, E., Shahzad, B., \& Alim, S. (2015). Impact of social media usage on students academic performance in Saudi Arabia. Computers in Human Behavior, 51, 1092-1097. https://doi.org/10.1016/j.chb.2014.09.028

[12] Aragon, S. R. (2003). Facilitating Learning in Online Environments: New Directions for Adult and Continuing Education. San Francisco: Wiley.

[13] Bosch, T. E. (2009). Using online social networking for teaching and learning: Facebook use at the University of Cape Town. Communication: South African Journal for Communication Theory and Research, 35(2), 185-200. https://doi.org/10.1080/02500160903250648

[14] Camilia, N. C., Ibrahim, S. D., \& Dalhatu, B. L. (2013). The effect of social networking sites usage on the studies of Nigerian students. The International Journal of Engineering and Science, 2, 39-46.

[15] Caruso, J. B., \& Salaway, G. (2008). The ECAR study of undergraduate students and information technology. ECAR Research Studies Colorado: EDUCAUSE Center for Applied Research, 1-4.

[16] Ciampa, M., Thrasher, E. H., \& Revels, M. A. (2016). Social Media Use in Academics: Undergraduate Perceptions and Practices. Journal of Educational Technology, 12(4), 1019.

[17] Cox, J. T., \& Rethman, K. M. (2011). Personal use of social networking by employeesBoth on the job and off the clock-Can cause major headaches for employers who fail to take the proper precautions, Ohio Lawyer.

[18] Curtis, A. (2013). The brief history of social media. Retrieved from: http://www.uncp.edu/home-/acurtis/NewMedia/SocialMedia/SocialMediaHistory.html

[19] Duhaney, D.C. (2005). Technology and higher education: Challenges in the halls of academe. International Journal of Instructional Media, 32(1), 7-15.

[20] Elsaadani, M. (2012). Exploration of teaching staff and students' preferences of information and communication technologies in private and academic lives. International Journal of Computer Science Issues, 9(2), 396-402.

[21] FBI (2013, 14th February 2014). Internet social networking risks. Retrieved from: http://www.fbi.gov/about-us/investigate/counterintelligence/internet-socialnetworkingrisks.

[22] Green, J., Wyllie, A., \& Jackson, D. (2014). Social networking for nurse education: Possibilities, perils and pitfalls. Contemporary Nurse, 47(1-2), 180-189. https://doi.org/10.1080/10376178.2014.11081919

[23] GreGory, P., GreGory, K., \& Eddy, E. (2014). The instructional network: Using Facebook to enhance undergraduate mathematics instruction. Journal of Computers in Mathematics and Science Teaching, 33(1), 5-26.

[24] Grosseck, G., \& Holotescu, C. (2011). Academic Research in 140 characters or less. Conference proceedings of "eLearning and Software for Education". Proceedings of the Seventh International Scientific Conference eLearning and Software for Education, pp.84-94. Bucharest, April 28-29.

[25] Havenstein, H. (2008). One in five employers uses social networks in hiring process. Computerworld.

[26] Junco, R., Heiberger, G., \& Loken, E. (2011). The effect of Twitter on college student engagement and grades. Journal of Computer Assisted Learning, 27(2), 119-132. https://doi.org/10.1111/j.1365-2729.2010.00387.x

[27] Kaplan, A. M., \& Haenlein, M. (2010). Users of the world, unite! The challenges and opportunities of Social Media. Business horizons, 53(1), 59-68. https://doi.org/10.1016/j.bushor.2009.09.003 
Paper-Undergraduate students' perceptions toward Social Media usage and academic performance...

[28] Karpinski, A. C., Kirschner, P. A., Ozer, I., Mellott, J. A., \& Ochwo, P. (2013). An exploration of social networking site use, multitasking, and academic performance among United States and European university students. Computers in Human Behavior, 29(3), 11821192. https://doi.org/10.1016/j.chb.2012.10.011

[29] Kitsantas, A., \& Chow, A. (2007). College students' perceived threat and preference for seeking help in traditional, distributed and distance learning environments. Computers and Education, 48(3), 383-395. https://doi.org/10.1016/j.compedu.2005.01.008

[30] Lau, W. W. (2017). Effects of social media usage and social media multitasking on the academic performance of university students. Computers in human behavior, 68, 286-291. https://doi.org/10.1016/j.chb.2016.11.043

[31] Layzell, P., Brereton, O., \& French, A. (2000). Supporting collaboration in distributed software engineering teams. Proceedings of the Seventh Asia-Pacific Software Engineering Conference, pp.38-45. Singapore: IEEE Computer Society. https://doi.org/10.1109/APSEC.2000.896681

[32] Leyrer-Jackson, J. M., \& Wilson, A. K. (2018). The associations between social-media use and academic performance among undergraduate students in biology. Journal of biological education, 52(2), 221-230. https://doi.org/10.1080/00219266.2017.1307246

[33] Lohnes, S., \& Kinzer, C. (2007). Questioning assumptions about students' expectations for technology in college classrooms. Innovate: Journal of Online Education, 3(5).

[34] Lorenzo, G., Oblinger, D., \& Dziuban, C. (2007). How choice, co-creation, and culture are changing what it means to be net savvy. Educause Quarterly, 30(1), 6-12.

[35] McFedries, P. (2007). All a-twitter. IEEE Spectrum, 44, 84-84. https://doi.org/10.1109/MSPEC.2007.4337670

[36] Moore, M., \& Kearsley, G. (2005). Distance Education: A Systems View. 2nd Edition, Belmont, CA: Wadsworth.

[37] Omekwu, C. O., Eke, H. N., \& Odoh, N. J. (2014). The use of social networking sites among the undergraduate students of University of Nigeria, Nsukka. Library Philosophy and Practice, 1, 1-26.

[38] Oye, N. D., Adam, M. H., \& Nor Zairah, A. R. (2012). Model of perceived influence of academic performance using social networking. International Journal of Computers and Technology, 2(2), 24-29.

[39] Paul, J. A., Baker, H. M., \& Cochran, J. D. (2012). Effect of online social networking on student academic performance. Computers in Human Behavior, 28(6), 2117-2127. https://doi.org/10.1016/j.chb.2012.06.016

[40] Porter, L. R. (2004). Developing an Online Curriculum: Technologies and Techniques. Information Science Publishing, Hershey: United State of America. https://doi.org/10.4018/978-1-59140-136-0

[41] Ravizza, S. M., Hambrick, D. Z., \& Fenn, K. M. (2014). Non-academic internet use in the classroom is negatively related to classroom learning regardless of intellectual ability. Computers and Education, 78, 109-114. https://doi.org/10.1016/j.compedu.2014.05.007

[42] Ross, J. G., \& Myers, S. M. (2017). The Current Use of Social Media in Undergraduate Nursing Education: A Review of the Literature. CIN: Computers, Informatics, Nursing, 35(7), 338-344. https://doi.org/10.1097/CIN.0000000000000342

[43] Smith, E. E. (2017). Social media in undergraduate learning: categories and characteristics. International Journal of Educational Technology in Higher Education, 14(1), 12. https://doi.org/10.1186/s41239-017-0049-y

[44] Subrahmanyam, K., Reich, S. M., Waechter, N., \& Espinoza, G. (2008). Online and offline social networks: Use of social networking sites by emerging adults. Journal of Applied Developmental Psychology, 29, 420-433. 
Paper-Undergraduate students' perceptions toward Social Media usage and academic performance...

https://doi.org/10.1016/j.appdev.2008.07.003

[45] Tamir, D. I., \& Mitchell, J. P. (2012). Disclosing information about the self is intrinsically rewarding. Proceedings of the National Academy of Sciences, 109(21), 8038-8043. https://doi.org/10.1073/pnas.1202129109

[46] Walker, C. M., Sockman, B. R., \& Koehn, S. (2011). An exploratory study of cyberbullying with undergraduate university students. TechTrends, 55(2), 31-38. https://doi.org/10.1007/s11528-011-0481-0

[47] Weaver, D., Spratt, C., \& Nair, S. C. (2008). Academic and student use of a learning management system: Implications for quality. Australasian Journal of Educational Technology, 24(1), 30-41. https://doi.org/10.14742/ajet.1228

[48] WiredSaftey. (2009). Direct attacks. Retrieved from: http://www.wiredsafety.com/

[49] Zhang, A. T., Land, L. P. W., \& Dick, G. (2010). Key influences of cyber bullying for university students.

\section{Author}

Mahdi Alamri is an assistant professor in Educational Technology department and Vice Dean of Scientific Research Deanship at King Faisal University, Alahsa, Saudi Arabia. He had his PhD degree in Educational Technology from LaTrobe University, Australia, in 2014. He also had his Master degree in Education Technology and his Bachelor degree in Special Education-Gifted and Talented Students' Education from King Saud University, SA, in 2005 and 2001 respectively. His research interests include Blended Learning, Online Learning, Flipped Classroom, Social Media Networks, Thinking Development Skills, Problem-based Learning and Special Education programmes.

Article submitted 04 August 2018. Resubmitted 14 and 15 October 2018. Final acceptance 15 October 2018. Final version published as submitted by the author. 